\title{
Development of Students' Management Skills in Pedagogical Activities of the Preschool Education Direction in Higher Educational Institutions
}

\section{TojiboevaNazokatkhonKobiljonovna ${ }^{1}$}

${ }^{1}$ Basic doctoral student of Tashkent state pedagogical university

\begin{abstract}
This article is devoted to the identification, theoretical substantiation and experimental verification of a set of pedagogical conditions, future teacher's managerial competence formation methods and stages in higher educational institutions.
\end{abstract}

Keywords: education, modernization, management, upbringing, development, research, preschool institution, pedagogy, management.

Article Received: 16th October, 2020; Article Revised: 30th December, 2020; Article Accepted: 08th January, 2021

Education today acts as one of the decisive factors in the society intellectual resources formation, ensuring its security and sustainable functioning.In these conditions, the importance of the education effectiveness and quality problem increases. The education entails modernization a requirements revision for the goals, training content and quality of the younger generation at all education levels.The education system decentralization, the variability and differentiation introduction of education force educational institutions separately and the education system as a whole to focus both on maintaining and improving the education quality that meets modern requirements and on the consumers needs of educational services.

Modernization in the preschool education has affected a number of aspects: new preschool educational institutions types have emerged, a large number of comprehensive and partial educational programs have been developed, new methods and work forms are being tested, the attestation mechanism and preschool educational institutions (PEI)accreditation has been tested, etc.
Consequently, the current situation in the preschool education necessitates the teachers and leaders preparation to manage the education quality, which is one of the important factors contributing to meeting the needs and expectations of various social groups of the population in quality education, upbringing and development, ensuring the child's rights to a full education, single educational space preservation.

In the preschool education, an increasing number of preschool workers are realizing the education quality dependence in PEI on its manageability level.However, many preschool leaders are still captivated by the formal approach to PEI management and see the improving management task in the "new approaches" introduction without taking into account the management activities context and organizational development.

It should be noted that the current situation in the preschool educational institutions management is characterized by the absence of a holistic, consistent theory and management.In a preschool educational institution management theory, the following are investigated:approaches to 
the individual management functions implementation (analysis, planning, organization, control); the management aspects (management of the teaching staff, the educational process management, financial and economic activities management) are highlighted;the approaches to managing the education quality in a preschool institution are defined (state educational standard, certification and accreditation as a mechanism for regulating the education quality, management monitoring as a means of improving the educational process quality, quality management of the educational process in a preschool institution).

The lag in the scientific substantiation development from the practice demands of education quality managing leads to a mechanical transfer of technologies, principles, and management theory recommendations to a preschool institution management, which does not always contribute to the effective management of a preschool institution.

Thus, the above allows us to speak about the contradictions presence between:

- the increased society need for highly qualified specialists capable of managing the education quality in a preschool institution, and the insufficient readiness of graduates of a pedagogical university to carry out this activity type;

- the need to prepare students to manage the education quality in a preschool institution and the insufficient development of theoretical justification and methodological support for this process.

Preparing students for managing the education quality in a preschool institution will proceed more effectively if the following sets of pedagogical conditions are met:

- designing meaningful preparation of students for managing the education quality in a preschool institution based on interdisciplinary integration;
- creation of comfortable conditions in the classroom (psychological, scientific and methodological, creative environment), contributing to the skills formation to manage the education quality in a preschool institution;

- the use of the "Portfolio" technology, which initiates the students' exit into a reflective position when studying a special course.

In accordance with the set goal and the hypothesis put forward, the following research tasks are determined:

1) to identify the problem state under study in psychological, pedagogical and managerial theory and practice, to determine promising approaches to its solution;

2) to clarify the essence and content of the basic concepts of the research: quality management of education in a preschool institution, the students readiness to manage the education quality in a preschool institution;

3) to develop a model for preparing students for managing the education quality in a preschool institution;

4) identify and experimentally test the pedagogical conditions complex for the effective functioning of this model;

5) on the basis of the study results, to develop scientific and methodological support for the students preparing process for quality management of education in a preschool institution

The pedagogical management concept is synonymous with the organizational and managerial activity of a teacher as principles complex, methods, organizational forms and technological methods of managing the educational process aimed at increasing its effectiveness.

Therefore, we can say: Management = Organizational and administrative activities.

Thus, the following components are incorporated in the organizational and managerial activity structure of vocational training teachers: 
- organizational - cognitive goals designation, results forecasting, determination of means and teaching methods;

- managerial - analysis, goal-setting and planning, organization and motivation, control and regulation.

Here are the most significant definitions of the concept of "pedagogical management".Pedagogical management is a complex of principles, methods, organizational forms and technological methods for managing the educational and educational process.Pedagogical management is a theory, methodology and technology of effective management of the educational process, based on a set of philosophical, pedagogical, social, psychological, and economic and management concepts, laws and patterns.

Pedagogical management - a set of principles, methods, organizational forms and technological methods of education management aimed at increasing its efficiency.

Pedagogical management, like any activity, has a purposeful character. This predetermines the need to isolate the main goals of pedagogical management in educational institutions and determine the rules for their scientifically grounded formulation.The following main goals of pedagogical management can be distinguished:

1) effective and systematic use of the forces, means and time of all employees of the educational institution and students;

2) determination of the managers activities compliance of the educational process in an educational institution with specific goals and real plans for the socioeconomic and spiritual development of society;

3) completeness, comparability, consistency, interconnectedness, concreteness and reality of certain goals and their subordination to the main goal training, education and development of a person as a free, responsible and creative person, his readiness formation for work, an active life position and a scientific worldview;

4) the algorithm for formulating goals shows that the correct definition of management goals should begin with an indefinite verb or in an imperative mood, characterizing the actions performed, and reflect the following basic provisions:

- to specify the required end result;

- to concretize the specified time frame for achieving the goal;

- to specify the maximum value of the permissible costs, efforts, funds, time and energy;

- give, where possible, a quantitative characteristic of the required work result, necessary to confirm the fact of achieving the goal;

- stipulate only "what" and "when" should be done, without going into the details of "how" and "why";

- respond directly to the intended purpose and functional responsibilities of this contractor;

- to be understandable to everyone who works to achieve this goal.

\section{The goal should be:}

- real and achievable, but not easy;

- provide a greater return on investment in time and resources than other possible goals;

- be implemented within the existing or expected time budget;

- exclude or make minimal the double responsibility possibility for the joint work result;

- comply with the basic principles and methods of the scientific labor organization;

- coincide with the interests of the performers and not cause conflicts in the organization;

- be recorded in writing;

- be coordinated by the manager in a personal conversation with subordinates.

Achieving the envisaged management goals requires the manager to have a clear understanding of the tasks to be solved. 
The main tasks of pedagogical management as a social activity system are determined by the following premises:

1) reflect the frequency and sequence of both individual actions of the performer and all his activities as a whole;

2) provide for methods and rules for performing certain work types for a specific period of time;

3) determine the requirements for the activities results quality and the intended goals achieving methods effectiveness, taking into account the efforts, funds and time optimality;

4) establish requirements for the composition and performers qualifications determined for a specific activity (in accordance with their functional responsibilities);

5) determine the amount of necessary information and its main sources from the optimality condition standpoint (necessity and sufficiency);

6) determine and provide for the basic rules for monitoring and recording the progress and the performers' activitiesresults.

\section{Functionsofpedagogicalmanagement.}

An important pedagogical management concept is its functions concept, which reflect the main management activities content, or rather, a complete cycle of certain actions in total and that make up management activities as a whole.In other words, a function is a relationship between a controlling system and a controlled object that requires the controlling system to take a certain action to ensure that the controlled processes are focused or organized.

There are several points of view on pedagogical management functions composition.

1. The planning function, or making a decision (orders, orders, recommendations, plans, council decisions, teachers council decisions, etc.).Planning the educational process (or making a decision) is the first main component (function) of pedagogical management, implemented through the definition of the main types of activities and activities, indicating specific performers, deadlines, taking into account the actual time budget available to this subject.Undoubtedly, any managerial influence is the result of a certain managerial decision made by a manager of a specific management level. The management solution must satisfy a number of requirements. Analysis of management theory and practice study shows that the solution should:

- have a targeted focus, i.e. fully comply with the pedagogical management goal;

- be justified, targeted (the executor and responsible for its implementation), and competent;

- be consistent, i.e. reflect the unity and consistency with the general system of made management decisions;

- meet the specificity condition in its implementation time and provide criteria for its implementation effectiveness, taking into account the expended forces, funds and time optimality;

- be relevant and timely;

- be complete, concise and clear.

Thus, the work plan for the academic year is an interconnected set of practical measures and activities for the implementation of the goals set for the educational institution, united by common goals, and the planning of training sessions is a specific act of making a decision on the construction of a general speculative or written model of interaction between the teacher and students during classes. The basis of this stage is the goal, objectives and real time of the lesson, as well as the principles, methods and content of the teaching and educational activities of the teacher and the educational and cognitive activities of students. Planning remains a formal act if there is no forecasting element at the planning stage.

2. The function of organizing the decisions and plans implementation includes:

- communicating the decision (plan) to the executor; 
- material and technical support for the possibility of implementing this decision (plan);

- this decision (plan) coordination with the attitudes and needs of the performer's personality (the second subject of management).

The organization of the decisions and plans implementation is the second basic component (second function) of pedagogical management, which is based on the principles of the scientific organization of labor (SOL).

3. Motivation function. The organization members must carry out their work in accordance with the responsibilities delegated to them. Leaders have always performed the motivation function, sometimes without even realizing it.

4.Control function. Let us define control as a system-forming factor of pedagogical management. Control is the main component (function) of pedagogical management, the process of obtaining and processing information about the course and results of the educational process and making management decisions on its basis.Control includes observation, study, analysis, diagnosis and evaluation of the effectiveness of the performers' activities.Analysis of the educational process is one of the main control methods in the pedagogical managementstructure; a way of obtaining knowledge about the reasons for a particular effectiveness of the joint activity of the teacher and students.

Preliminary control involves checking plans, other types of control are coordinating the performers activities based on the information obtained during this control, recording the activitiesresults, analyzing and assessing its effectiveness based on this controlresults.

Together, these functions reflect the course and sequence of certain management actions, their completed cycle.

The scientific novelty of the research is that:

- a model for preparing students for managing the education quality in a preschool institution has been developed, including target, content, organizational and technological and evaluative and effective components;

- a set of pedagogical conditions has been theoretically substantiated and experimentally tested, which ensures the effective functioning of this model in the process of training students.

The theoretical study significance is as follows:

- clarified the content of the concepts "education quality management in a preschool institution", "readiness of students to manage the quality of education in a preschool institution";

- on the basis of the developed model, the principles of the implementation of the methodology for preparing students for the education quality management in a preschool institution are determined, a meaningful characteristic of this process components is given.

The practical research significance is determined by the fact that scientific and methodological support of the process of preparing students for managing the education in quality a preschool institution has been developed: methodological recommendations for the special course "Quality management of education in a preschool institution", assessment and criteria tools for diagnosing the students' readiness level for quality management education at PEI.Conclusions and recommendations for preparing students to manage the quality of education in a preschool institution will serve to improve their professional training. The developed components of the education quality in PEI, functions, quality management stages in education in PEI can be used in the practice of the heads of preschool institutions, and will also be of interest to specialists of educational authorities. The results of the research can be used in the system of advanced training of pedagogical and executive employees of preschool educational institutions. 
Conclusion: This study is devoted to the development of students preparing process model for the management of the education quality in a preschool institution and the pedagogical conditions identification for its effective functioning.In accordance with this goal, the hypothesis was based on the assumption that the preparation of students for the management of the quality of education in a preschool institution will proceed more efficiently if the following set of pedagogical conditions is implemented:designing students meaningful preparation for managing the education quality in a preschool institution based on interdisciplinary integration; creation of comfortable conditions in the classroom (psychological, scientific and methodological, creative environment), contributing to the formation of skills to manage the education quality in a preschool institution; the use of the "Portfolio" technology, which initiates the students' exit into a reflective position when studying a special course.

Solving the tasks necessary to prove this hypothesis, we clarified the concepts of "education quality in PEI", " education quality management in a preschool institution", "readiness to manage the education quality in a preschool institution", developed a model of the process under study, as well as theoretically substantiated and experimentally tested a complex of pedagogical conditions for its effective functioning.

The starting point in our study was the conceptual field analysis of the indicated problem.Based on the philosophical, managerial, psychological, pedagogical and economic interpretations of the concepts of "quality", "education quality ", "management", "quality management", " education quality management", we have identified the education quality components in PEI:target, meaningful, organizational-activity and effective.Taking into account the education quality components in a preschool institution presented by us and relying on the process approach, which considers quality management as a process, we have identified functions (information and analytical, planning and prognostic, motivational and value, organizational and activity, control and evaluation), stages and specific actions to manage the education quality in a preschool institution.

The "students readiness to manage the education quality in a preschool institution" concept was defined as readiness for management, which is an integrative education of a person with a systemic organization, acting as an integral interaction of cognitive, subject-practical and reflective components, the formation degree which determines the process specifics, aimed at creating an educational service of optimal quality.

This understanding of this category determined our approaches to designing a model of a system for preparing students for managing the education quality in a preschool institution and identifying a complex of pedagogical conditions that ensure its effective functioning. The model is clearly focused on a specific goal preparing students to manage the quality of education in a preschool institution. The principles of interdisciplinary integration, consistency, manufacturability, professional orientation, flexibility, modularity and personal awareness became the scientific support for the model we designed.

To obtain objective information about the students' readiness level to manage the education quality in a preschool institution, a set of criteria was determined: knowledge of education quality managing in PEI; the ability to manage the education quality at PEI; the student's personal growth reflection.The testing results reliability the model effectiveness under study against the background of the complex implementation of pedagogical conditions 
is ensured by using the student's advancement to a higher level of readiness to manage the quality of education in PEI as the main diagnostic criterion.

The general didactic significance of the study results was proved during this model implementation in the pedagogical process of the Preschool education faculty of Magnitogorsk state university.Experimental and experimental work carried out with students provided a high level of readiness to manage the quality of education at PEI, which confirms our research results.

\section{References:}

[1] Abdullina O.A. General pedagogical training of teachers in the system of higher pedagogical education: textbook. manual for ped. specialties of universities / O. A. Abdullina. M $\therefore$ Education, 1990. - $141 \mathrm{p}$.

[2] Abdullina O. A. Monitoring the quality of professional training / $\mathrm{O}$. A. Abdullina // Higher education in Russia. 1998. - № 3. - p. 35-39.

[3] Averyanov A.N. Systemic knowledge of the world: Methodological problems / A.N. Averyanov. M : Politizdat, 1985. $263 \mathrm{p}$.

[4] Andreev V. I. Pedagogy of creative self-development / V. I. Andreev. Kazan: Publishing house of Kazan, university, 1996. 597p.

[5] Afanasyev V.V. Management problem as an object of pedagogical research / V. V. Afanasyev, P. I. Pidkasisty // Pedagogy. 2001. - № 5.p. 12-17.

[6] Babansky Yu. K. Selected pedagogical works / Yu. K. Babansky; comp. M. Yu. Babansky; ed. Art. G.N. Filonov. M.: Pedagogy, 1989. $-558 \mathrm{p}$.

[7] Babunova T.M. Modernization of the content of the educational process of a preschool institution / T.M.Babunova // Actual problems of preschool education: collection of scientific articles. Magnitogorsk: MSU, 2003. - p. 41-45.

[8] Baturina G.I. Introduction to the teaching profession: textbook / G.I.Baturina, T.F. Kuzina. M .: Academy, 1998. - 176 p.

[9] V.S.Bezrukova Pedagogy. Projective pedagogy: a textbook for technical schools and universities / V.S.Bezrukova.

Ekaterinburg:Affairs. book.,1996. $344 \mathrm{p}$.

[10] Belikov V.A. Image and logic in the presentation of the course "Pedagogical theories, systems and technologies" / V.A.Belikov. Magnitogorsk: MSU, 2000. -67 c.

[11] BelikovV.A.Methodological foundations for solving the problem of organizing student activity: Monograph / V.A. Belikov, N.G. Krivoschapova. Magnitogorsk: MSU, 2004. - $121 \mathrm{c}$.

[12] BelikovV.A.Education. Problemoriented analysis based on the activity approach: Monograph / V. A. Belikov, JI. A. Savinkov. Magnitogorsk: MSU, 2004. - 116 p

[13] Belov V. System for assessing the quality of education / V. Belov // Higher education in Russia.2002. № 1. - p. 44-49.

[14] Belyaeva A.P. Trends in the development of vocational education / A.P. Belyaeva//Pedagogy. 2003. № 2. - p. 21-27.

[15] Bordovsky G.A. Quality management of the educational process / G. A. Bordovsky, A. A. Nesterov, S. Yu. Trapitsin. SPb .Publishing house of the Russian State Pedagogical University named after A. I. Herzen, 2001. - 359 p.

[16] Bukaev I. V. Organizational and pedagogical conditions of conflict management in the primary production team: dis. Cand. ped. Sciences / I. V. Bukaev. Magnitogorsk, 2004. - 166 p. 
[17] 17. Bulynskiy NN Theory and practice of education quality management in vocational schools: author. dis. Dr. ped. Sciences / N.N.Bulynsky. Chelyabinsk, 1997. $37 \mathrm{p}$.

[18] Introduction to the pedagogical profession / ed. A. S. Robotova. -M .: Academy, 2002. 208p.

[19] Gershunsky B.S. Philosophy of education for the XXI century (In search of practice-oriented educational concepts) / B.S.Gershunsky. -M.: «Inter Dialect +», 1997. 697p.

[20] Granatov G.G. Method of complementarity in the development of concepts (pedagogy and psychology of thinking): Monograph / G.G. Granatov. Magnitogorsk: MSU, -2000.-195 p.

[21] Gutnik G.V. Information support of the education quality management system in the region / G.V. Gutnik // Informatics in education. 1999. -№4.p. 32-36. 